\title{
AS PLANTAS
}

Eduardo Carrascosa é Doutor em Ciências Sociais pela Unicamp-SP e professor de Sociologia da Universidade Candido MendesRJ. E-mail: eduardocarrascosa@yahoo.com.br

As plantas que ela cultivava em meus vasinhos continuam vivas mesmo na sua ausência. Rego e cuido com carinho como se para mantê-la por perto. Verdejam e alegram minha solidão vegetativa. Peguei até uma muda de Espada-de-São-Jorge pra me proteger não sei bem do quê.

O pé de manjericão tá bonito que só vendo, nem aí pra minha saudade. O cacto no potinho da Harrods parece bem também, mas não me dá muito papo. É um cara seco. O Dinheiro-em-penca todo fim de mês murcha, mas ganha força no $5^{\circ}$ dia útil. Recebe atenção especial pois pior que viver num mundo cão é viver num vira-lata. Só a roseira, antes tão florida, símbolo meio brega que guardei como souvenir de um amor espinhoso, secou e parece morta.

Outro dia, Iara, a senhora que faz uma faxina quase espiritual aqui em casa, sem dar muita atenção aos detalhes mais mundanos como poeira e gordura, podou os galhos. Parece que ela acredita na ressurreição, macumbeira que é. Resolvi então dar mais uma chance àquela flor, pois ela não é culpada de não sabermos o lugar certo onde colocar nossos desejos e fantasmas. Arranquei as ervas daninhas, troquei de pote, pois o anterior estava caindo aos pedaços, aparentemente querendo me dar um toque sobre os destinos de minha sanidade, e replantei num baldinho de sorvete, com furinhos no fundo feitos com prego quente. Apesar de todo o zelo e boa intenção, não é que a ingrata enfiou um espinho na mão que tentava salvá-la! Doeu e sangrou, como se o amor estivesse vivo. 